Michał Kondratiuk

Uniwersytet w Białymstoku

\title{
O współpracy zespołu Pracowni Filologii Białoruskiej IS PAN z prof. Władysławem Kuraszkiewiczem w zakresie badania gwar
}

Dla uzmysłowienia stanu białorutenistyki w Polsce po drugiej wojnie światowej, należy choć na chwilę cofnąć się do czasu powstania Białorusi i Białoruskiej Socjalistycznej Republiki Radzieckiej (BSRR), określić stan wiedzy i zainteresowanie problematyką białoruską w Polsce międzywojennej, czyli w II Rzeczypospolitej.

Na mocy ryskiego traktatu pokojowego z 18 marca 1921 roku (kończącego wojnę polsko-radziecką 1919-1920) wschodnia część Białorusi jako BSRR weszła (1922) w skład ZSRR, a zachodnia została przyłączona do Polski w maju 1919 roku.

W BSRR niegdyś chłopskie narzecze w początkach XX wieku stawało się językiem literackim. Władza radziecka nobilitowała język białoruski, wprowadziła go do instytucji państwowych, do szkół i uniwersytetów. Język białoruski uzyskał rangę jednego z języków narodowych. Rozwijała się białoruska kultura, literatura i nauka.

Wysiłki polskich władz administracyjnych szły w kierunku ograniczenia szkół z białoruskim językiem nauczania. Obawiano się, że w podzielonym narodzie może się rozwinąć potężne dążenie do zjednoczenia, zagrażające interesom państwa polskiego.

O stosunkowo niewielkim zainteresowaniu kulturą i literaturą rosyjską, białoruską i ukraińską w Polsce okresu międzywojennego (1918-1939) piszą historycy literatur wschodniosłowiańskich: Marian Jakóbiec [1989: 29-63, szczególnie 39, 47-48, 62-63], Włodzimierz Stochel [1987: 289-311] i Bazyli Białokozowicz [2000: 448-453]. Jakóbiec zauważa, iż 
[n]ad Polakami ciągle jeszcze ciążyły tradycje niewoli, antyrosyjskie kompleksy, czasem sceptyczny, a czasem wręcz wrogi stosunek do wszelkich programów słowiańskich mających jakikolwiek związek z dawną polityką carów. Poważną przeszkodą w należytym ułożeniu stosunku do kultury tych narodów były zakorzenione od wieków tradycje okcydentalistyczne i związana z tym orientacja kulturalna warstw nadających ton życiu umysłowemu kraju, w którym na dodatek znalazły się miliony Ukraińców i Białorusinów,

a dalej stwierdza, że w Wielkiej literaturze powszechnej pod redakcją Stanisława Lama (t. 4, Warszawa 1933, s. 539-546) znalazł się, niestety, tylko ośmiostronicowy szkic o literaturze białoruskiej jedynego w Polsce historyka literatur słowiańskich o najszerszym zasięgu, docenta tych literatur na Uniwersytecie Warszawskim, Józefa Gołąbka, który był także autorem m.in. prac $\mathrm{z}$ folkloru białoruskiego.

Jeszcze mniej miejsca, bo tylko trzy strony najogólniejszej informacji, poświęcił literaturze białoruskiej Aleksander Brückner w Zarysie dziejów literatur i języków literackich słowiańskich autorstwa swojego i Tadeusza Lehra-Spławińskiego (Lwów 1929, Lwowska Biblioteka Slawistyczna, IX).

Stochel i Białokozowicz wspominają jeszcze o pionierskich na lata 20. i 30. Zarysach literatury białoruskiej Bohdana Żyranika (Warszawa 1921), Krótkim zarysie literatury białoruskiej Maksima Hareckiego (Wilno1921), Uwagach nad literatura białoruska Marii Rudzińskiej-Froelichowej (Wilno 1936) oraz innych artykułach i przyczynkach o literaturze białoruskiej i jej związkach $\mathrm{z}$ literaturą polską.

Natomiast w Niemczech ukazała się znakomita historia białoruskiego folkloru i literatury pióra twórcy naukowej białorutenistyki, przed pierwszą wojną światową profesora (rektora) Uniwersytetu Warszawskiego, a później członka Akademii Nauk ZSRR Jewfimija Karskiego (Geschichte der weissrussischen Volksdichtung und Literatur, Berlin 1926). Jego niemiecka książka była częściowym tłumaczeniem wielkiego dzieła „Biełorusy” (1903-1922). Poza opracowaniem Karskiego nie było w krajach zachodnich prób szerszego spojrzenia na kulturę i literaturę białoruską.

W krajach słowiańskich stosunek do kultury i literatury rosyjskiej, ukraińskiej i białoruskiej nie był jednolity. Najlepsze warunki dla rozwoju slawistyki, w tym także wschodniosłowiańskiej, zaistniały w mieszczańskiej, liberalno-demokratycznej Czechosłowacji. Wiązały się one z przejęciem w spadku po carskiej Rosji ideologii neoslawizmu, haseł solidarności narodów słowiańskich pod egidą carskiej Rosji. Twórcą tej ideologii był Czech Karel Kramar. Ponadto istniały tu bogate tradycje słowianofilskie, sięgające czasów Szafarika 
i Kollara. Korzystano przy tym również z wykładowców - emigrantów ze środowisk Słowian wschodnich. W roku 1928 założono w Pradze słynny Instytut Słowiański (Slovanský ústav). To przede wszystkim dzięki niemu Praga stała się w dwudziestoleciu międzywojennym światowym centrum studiów slawistycznych, w tym także wschodniosłowiańskich.

W okresie międzywojennym w centrum zainteresowania polskich językoznawców, etnografów, socjologów i historyków znalazło się Polesie Wschodnie, dzięki staraniom Komisji Naukowych Badań Ziem Wschodnich. Największe osiągnięcia mamy tu w zakresie etnografii i folkloru związane z pracami Kazimierza Moszyńskiego [1921: 1-19; 1928], Czesława Pietkiewicza [1928; 1938] i folklorysty Michała Federowskiego [zob. Bibliografia], a także innych badaczy.

Badania dialektologów polskich tego okresu koncentrują się głównie wokół gwar przejściowych białorusko-ukraińskich na Polesiu i gwar polsko-ukraińskiego czy polsko-białoruskiego pogranicza. Pionierami tych badań byli Leszek Ossowski [1992]1', Józef Tarnacki [1939; red. 1939], Kazimierz Nitsch [1954-1958; 1960], Władysław Kuraszkiewicz [1963; 1985], a także Karol Dejna, Zdzisław Stieber, Jan Tokarski i inni. Na podkreślenie zasługują prace Haliny Turskiej, zwłaszcza studium dotyczące powstania polszczyzny na substracie białoruskim i litewskim, tj. O powstaniu polskich obszarów językowych na Wileńszczyźnie [zob. Rieger, Werenicz, red. 1982; Turska 1995].

Ze strony polskiej nie podjęto badań gwar zachodniobiałoruskich, a polsko-białoruska granica polityczna w okresie międzywojennym paraliżowała akcję badań dialektologicznych w Republice Białoruskiej, co wyraźnie widać na przykładzie map Piotra Buzuka w jego pracy Sproba linhwistycznaje hieahrafii Biełarusi [Бузук 1928]. Na uboczu zainteresowań polskich językoznawców pozostawały gwary zachodniobiałoruskie, leżące w obecnych granicach Polski, w przybliżeniu między Kanałem Augustowskim na północy a rzeką Bug na południu, poza cenną rozprawą Kuraszkiewicza zatytułowaną Najważniejsze zjawiska językowe ruskie w gwarach między Bugiem i Narwia [Kuraszkiewicz 1939], informacjami Kazimierza Nitscha oraz Zdzisława Stiebera z okolic Augustowa, Studzienicznej, Suchej Rzeczki i Mikaszówki [Nitsch, Stieber 1938].

W wyniku drugiej wojny światowej zmieniły się polskie granice polityczne, ziemie Białorusi Zachodniej zostały włączone do Republiki Białoruskiej. W Polsce powojennej nastąpiły istotne zmiany w badaniach slawistycznych.

1 Jest to przedruk prac prof. Leszka Ossowskiego rozproszonych w różnych czasopismach i książkach, wybranych i zredagowanych przez prof. Stanisława Glinkę. 
W procesie organizacji i reorganizacji życia naukowego powstały nowe uniwersytety, wyższe szkoły pedagogiczne, Polska Akademia Nauk oraz inne placówki naukowe i oświatowe, w których podjęto badania slawistyczne, w tym także w zakresie językoznawstwa i literaturoznawstwa wschodniosłowiańskiego.

Początki instytucjonalnego oparcia filologii białoruskiej w powojennej Polsce wiążą się z działalnością byłego Instytutu Polsko-Radzieckiego przy ul. Foksal w Warszawie i utworzonej tam Pracowni Filologii Białoruskiej i Pracowni Filologii Ukraińskiej, którą w latach 1953-1957 kierowała prof. dr Antonina Obrębska-Jabłońska. W wyniku reorganizacji tego Instytutu Pracownia Filologii Białoruskiej 1 grudnia 1957 roku została włączona do Zakładu Słowianoznawstwa PAN (od 1977 roku Instytutu Słowianoznawstwa, dziś Instytutu Slawistyki PAN). W roku 1956 decyzją władz politycznych i oświatowych PRL na Wydziale Filologicznym Uniwersytetu Warszawskiego została powołana Katedra Filologii Białoruskiej oraz otwarty nowy kierunek studiów: filologia białoruska [Беларускі... 1959: 70; Баршчэўскі 1982: 59-65]. Organizatorem i kierownikiem naukowym obu placówek była prof. Obrębska-Jabłońska, która z wielkim zaangażowaniem, sercem i talentem organizacyjnym pokonywała wiele problemów stojących na drodze do utworzenia tych instytucji i zapewnienia im prawidłowego funkcjonowania. Największe trudności w realizacji postawionych celów i zadań były związane z zapewnieniem odpowiedniej kadry naukowo-dydaktycznej, niezbędnej literatury, programów studiów, podręczników i skryptów.

W powojennej Polsce brakowało wykwalifikowanej kadry nauczycieli akademickich w zakresie białoruskiej literatury i języka. Nieliczni profesorowie slawiści, zajmujący się językami wschodniosłowiańskimi i literaturą narodów rosyjskiego, białoruskiego czy ukraińskiego byli pochłonięci organizacją katedr rusycystycznych bądź polonistycznych w odradzających się - po ciężkich stratach kadrowych w okresie okupacji niemieckiej - uniwersytetach i nowo powstających wyższych szkołach pedagogicznych. Należeli do nich np. profesorowie i docenci: Stefan Hrabec, Karol Dejna, Marian Jakóbiec, Władysław Kuraszkiewicz, Mścisław Olechnowicz, Leszek Ossowski, Maria Rudzińska-Froelichowa, Tadeusz Lehr-Spławiński. Jedyny badacz w owym czasie o rusycystycznym wykształceniu prof. Jan Otrębski poświęcił się prawie całkowicie bałtystyce.

Jak wyżej wspomniano, zalążkiem przyszłej Pracowni Filologii Białoruskiej w Instytucie Słowianoznawstwa Polskiej Akademii Nauk w Warszawie był zespół liczący dwie osoby plus kierownik zatrudniony w niepełnym wymiarze godzin w dawnym Instytucie Polsko-Radzieckim w Warszawie. Z inicjatywy i pod kierunkiem prof. Obrębskiej-Jabłońskiej w roku 1955 w tym zespole 
rozpoczęte zostały badania gwar wschodniosłowiańskich Białostocczyzny typu atlasowego, zaś od 1 grudnia 1957 roku były one kontynuowane w ramach Instytutu Słowianoznawstwa PAN. W roku 1958 w skład zespołu wchodzili: Stanisław Glinka, Michał Kondratiuk, Antonina Obrębska-Jabłońska (kierownik), Elżbieta Smułkowa oraz Halina Petruczynik. W pracy nad atlasem można wydzielić kilka etapów. Lata 1955-1958 były etapem przygotowawczym. W tym czasie określono w przybliżeniu zasięg gwar wschodniosłowiańskich na Białostocczyźnie, przeprowadzono badania wstępne (zebrano słownictwo w kilku punktach próbnych), ustalono siatkę punktów oraz opracowano kwestionariusz, stanowiący podstawę dalszej pracy. Lata 1958-1962 to okres wytężonej pracy terenowej, zgromadzono wtedy znaczną część materiałów gwarowych. W latach 1962-1970 rozpisywano zebrany materiał na kartki, sporządzono ponad 1500 map napisowych. Następnie przejrzano krytycznie zebrane materiały, przygotowano projekt atlasu i przeprowadzono badania uzupełniające, opracowano także pięć punktów dodatkowych, co pozwoliło ustalić dokładniej zasięgi wielu faktów językowych. Opracowano również pierwszy tom Atlasu gwar wschodniostowiańskich Białostocczyzny [zob. Bibliografia] i wykonano wiele map brulionowych.

Tom 1 wymienionego Atlasu... oprócz materiałów informacyjnych (wstępu, artykułu o historii osadnictwa na Białostocczyźnie, spisu eksploratorów, wykazu i opisu badanych wsi, liczącego około 1800 pytań kwestionariusza i 8 map pomocniczych) zawiera 42 mapy fonetyczne z komentarzami. Każdy następny tom zawiera po 100 map z komentarzami, t. 2 poświęcony jest całkowicie fonetyce, t. 3 ma 25 map początkowych z zakresu fonetyki, a reszta dotyczy fleksji rzeczowników.

Atlas gwar wschodniostowiańskich Białostocczyzny miał na celu:

a) przedstawić metodą geografii lingwistycznej najważniejsze dane z zakresu fonetyki, morfologii i leksyki dialektów wschodniosłowiańskich Białostocczyzny. Dane te będą stanowić uzupełnienie innych atlasów słowiańskich i podstawę do badania polszczyzny powstałej na substracie wschodniosłowiańskim;

b) pokazać związki językowe białorusko-ukraińskie na odcinku zachodnim;

c) wskazać kontakty badanych dialektów z sąsiednimi gwarami polskimi i polskim językiem literackim;

d) pokazać wpływ języka litewskiego na dialekty słowiańskie Białostocczyzny.

Trzeba podkreślić, że recenzentem naukowym pierwszych trzech tomów był prof. Władysław Kuraszkiewicz (t. 1 - razem z prof. Zdzisławem Stieberem, t. 2 - sam, t. 3 - z prof. Leszkiem Ossowskim). 
Oto fragment recenzji (maszynopis) tomu 3 Atlasu ..., sporządzonej przez prof. Kuraszkiewicza:

Zespołowo opracowany III tom Atlasu Białostocczyzny pod kierunkiem doc. dra hab. Stanisława Glinki zawiera razem 100 map szczegółowych. Z tego 20 map ilustruje zjawiska fonetyczne na przykładach niekiedy już zleksykalizowanych oraz 75 map przedstawia wybrane zjawiska z fleksji rzeczowników. Zjawiska te są dobrze wybrane z masy zebranego materiału dla pokazania opozycji terenowych w tych gwarach przejściowych, głównie z zakresu tendencji białoruskich i ukraińskich oraz wpływu gwar polskich od zachodu. W komentarzach do map przytoczono wiele szczegółowych materiałów pominiętych na mapach, jak np. rozchwianie wymowy w wielu punktach, dodatkowe zjawiska lokalne itp.

Opracowanie przedstawionego tomu jest dokładne, podobne do tomów poprzednich, nie budzi żadnych wątpliwości merytorycznych. Jest dalszym wzbogaceniem naszej wiedzy rusycystycznej i slawistycznej tak w zakresie badanych gwar, jak i dla gramatyki porównawczej. Powinien być drukowany w przygotowanym zakresie równie starannie jak i tom I. [...]

Omawiany tom jak i poprzednie dwa tomy dobrze uzupełniają wydane już atlasy gwar białoruskich i ukraińskich i to też jest cenne.

Profesor Kuraszkiewicz był inicjatorem opracowania Atlasu gwar wschodniostowiańskich Pobuża. W roku 1985 prace nad tym atlasem rozpoczęły dwa zespoły: Pracownia Filologii Białoruskiej Instytutu Słowianoznawstwa PAN w Warszawie oraz Instytut Filologii Rosyjskiej i Słowiańskiej UMCS w Lublinie. Eksplorację materiałów prowadzono według kwestionariusza do Atlasu gwar wschodniosłowiańskich Białostocczyzny. Uczestnikami badań ze strony Instytutu Słowianoznawstwa PAN byli: Piotr Cetra, Grażyna Czaplak, Katarzyna Karabowicz, Michał Kondratiuk, Roman Roszko, a z Uniwersytetu Marii Curie-Skłodowskiej: Feliks Czyżewski, Jan Ignaciuk, Michał Łesiów, Michał Sajewicz, Stefan Warchoł. Badania trwały od 1985 do 1991 roku. Większość materiałów w oryginale znalazła się w byłej Pracowni Języka Białoruskiego Instytutu Słowianoznawstwa (dziś Instytutu Slawistyki) PAN w Warszawie. Stan badań nad gwarami ukraińskimi Pobuża od roku 1985 do 1990 dokładnie przedstawił prof. Feliks Czyżewski, w tomie 36 „Rozpraw Komisji Językowej Łódzkiego Towarzystwa Naukowego". Badania wstrzymano ze względu na brak środków finansowych oraz restrukturyzację Instytutu Słowianoznawstwa prowadzoną przez nowe kierownictwo Instytutu, powołane w wyniku zmian ustrojowych. Najpierw praktycznie zlikwidowano Pracownię Literatur Wschod- 
niosłowiańskich, a potem przekształcono pracownie poszczególnych literatur i języków w zespoły badawcze, do których mogli należeć specjaliści różnych języków i literatur.

Profesor Kuraszkiewicz, członek rzeczywisty PAN, wniósł znaczny wkład w rozwój kadry naukowej Pracowni Filologii Białoruskiej. Recenzował pracę doktorską Elżbiety Smułkowej, pracę doktorską Stanisława Glinki oraz uczestniczył w przewodzie habilitacyjnym dra Glinki, był recenzentem pracy doktorskiej Kazimiery Janiak i innych.

Na początku 1990 roku w Warszawie powstała grupa inicjatywna (Aleksander Barszczewski, Albert Bartoszewicz, Maria Czurak, Michał Kondratiuk, Zofia Skibińska-Charyło, Włodzimierz Stochel i inni), która postawiła sobie zadanie - powołać Międzynarodową Asocjację Białorutenistów (MAB). Sprawa ta była uprzednio uzgadniana i dyskutowana z przedstawicielami środowisk białoruskich w Mińsku i innych ośrodków akademickich, a także z niektórymi białorutenistami z różnych krajów. Dobrą okazją do urzeczywistnienia tego zamiaru była obchodzona przez UNESCO 500. rocznica urodzin Franciszka Skoryny, białoruskiego drukarza, uczonego i działacza oświatowego, oraz organizowana przez Komitet Słowianoznawstwa PAN przy współudziale Katedry Filologii Białoruskiej UW, Filii Uniwersytetu Warszawskiego w Białymstoku i Białoruskiego Towarzystwa Społeczno-Kulturalnego w Polsce międzynarodowa konferencja naukowa (18-20 czerwca 1990 roku).

$\mathrm{Na}$ konferencji wysłuchano w ciągu dwóch dni 20 referatów uczestników krajowych i zagranicznych, po czym przystąpiono do części poświęconej powołaniu organizacji - Międzynarodowego Stowarzyszenia Białorutenistów (MSB). Zapoznano zebranych z przebiegiem dotychczasowych prac przygotowawczych grupy inicjatywnej do przeprowadzenia zebrania założycielskiego MSB. W dyskusji o potrzebie powołania do życia MSB, jego celach, zadaniach i strukturze wewnętrznej głos zabierało wielu mówców, m.in.: Adam Maldzis, Albert Bartoszewicz, Aleksander Barszczewski, Czesław Seniuch, Mikołaj Biryło, Bazyli Białokozowicz, Aleh Łojka, Aleksy Kawka, Mikałaj Nikołajew, Michał Kondratiuk, Leon Tarasewicz. Dyskutanci i wszyscy uczestnicy (53 osoby) zebrania założycielskiego MSB przyjęli Deklarację o utworzeniu Międzynarodowego Stowarzyszenia Białorutenistów oraz apel-prośbę do Rady Ministrów BSRR i Prezydium Akademii Nauk BSRR o okazanie wsparcia i pomocy w organizacji zjazdu założycielskiego w 1991 roku w Mińsku. Powołano Komitet Organizacyjny MSB, który miał opracować projekt Statutu MSB, program działania i zorganizować I Zjazd MSB.

W skład Komitetu Organizacyjnego MAB (w wyniku tajnych wyborów) weszli: Adam Maldzis (przewodniczący), Hienadź Cychun (sekretarz), wice- 
przewodniczącymi zostali: Tomas Bird (USA), Jim Dingley (Wielka Brytania), Karl Gutschmidt (Niemcy), Aleksy Kawka (Rosja), Michał Kondratiuk (Polska). Członkami Komitetu w głosowaniu jawnym zostali wybrani: Uładzimir Aniczenka, Mikałaj Biryła, Aleh Łojka (Białoruś), Mikałaj Nikołajew (Rosja), R. Jewtimowa (Bułgaria), Witold Kipiel (USA), Aleksander Barszczewski, Albert Bartoszewicz, Tadeusz Lewaszkiewicz, Elżbieta Smułkowa (Polska). Protokół z zebrania założycielskiego MAB 19 czerwca 1990 roku w Warszawie sporządził Jan Czykwin (Dokumentacja w Komitecie Słowianoznawstwa PAN).

Obie zorganizowane imprezy - międzynarodowa konferencja naukowa poświęcona obchodom 500-lecia urodzin Franciszka Skoryny i zebranie naukowe związane $\mathrm{z}$ omówieniem stanu i perspektyw rozwoju białorutenistyki polskiej oraz powołaniem Polskiego Towarzystwa Białorutenistów znalazły powszechną aprobatę i uznanie polskich filologów i historyków, o czym świadczą licznie przybyli uczestnicy tych spotkań i listy nadesłane do organizatorów wymienionych imprez naukowych (życzenia przesłali m.in. profesorowie: Marian Jakóbiec, Telesfor Poźniak, Franciszek Sielicki z Wrocławia, Władysław Kuraszkiewicz, Marceli Kosman, Tadeusz Zdancewicz z Poznania, Ryszard Łużny z Krakowa, Michał Łesiów z Lublina, dr Tadeusz Gasztold z Koszalina, Jim Dingley z Londynu). Do Polskiego Towarzystwa Białorutenistycznego wstąpiło po jego powołaniu około 70 osób.

W opublikowanym potem Statucie Międzynarodowej Asocjacji Białorutenistów czytamy m.in.:

Międzynarodowa Asocjacja Białorutenistów (Internacional Association of Byelorussist) skupia pracowników naukowych, wykładowców, działaczy kultury, tłumaczy z różnych krajów świata, którzy badają zdobycze kulturalne narodu białoruskiego i wzbogacają je, sprzyjają odrodzeniu narodowemu i rozwojowi Białorusinów, służą wzajemnemu umacnianiu związków Białorusinów z innymi narodami... Członkami MAB mogą też być studenci i zwolennicy białoruskiego języka i kultury.

\section{Bibliografia}

Atlas gwar wschodniosłowiańskich Białostocczyzny, t. 1, red. Stanisław Glinka, Antonina Obrębska-Jabłońska, Janusz Siatkowski, Slawistyczny Ośrodek Wydawniczy, Wrocław 1980; t. 2, 3, red. Stanisław Glinka, Ossolineum, Wrocław 1989, 1993; t. 5-8, red. Irena Maryniakowa, Ossolineum, Warszawa 1995, 1996, 1999, 2003; t. 4, Słowotwórstwo, Slawistyczny Ośrodek Wydawniczy, Warszawa 2012. 
Białokozowicz Bazyli (2000), Polsko-białoruskie zwiazki literackie, w: Literatura polska XX wieku. Przewodnik encyklopedyczny, red. Artur Hutnikiewicz, Andrzej Lam, t. 2, Wydawnictwo Naukowe PWN, Warszawa.

Federowski Michał, Lud białoruski, t. 1-3, Kraków 1897, 1902, 1903; t. 4, Warszawa 1935; t. 5-7, red. Antonina Obrębska-Jabłońska, PWN, Warszawa 1958, 1960, 1969; t. 8, Inedita. Pieśni z archiwum zbieracza, oprac. Maria Czurak, PWN, Warszawa 1981.

Jakóbiec Marian (1989), Międzywojenny dorobek slawistyki zachodniej i środkowoeuropejskiej w zakresie syntez historii literatury rosyjskiej i innych literatur wschodniostowiańskich, w: Stowianoznawstwo w okresie międzywojennym (1918-1939), cz. 1, red. Mieczysław Basaj, Stanisław Urbańczyk, Zakład Narodowy im. Ossolińskich, Wrocław, s. 29-64.

Kuraszkiewicz Władysław (1939), Najważniejsze zjawiska językowe ruskie w gwarach między Bugiem i Narwia, „Sprawozdania Komisji Językowej Towarzystwa Naukowego Warszawskiego", t. 31, z. 2, s. 104-119.

Kuraszkiewicz Władysław (1963), Zarys dialektologii wschodniosłowiańskiej z wyborem tekstów gwarowych, wyd. 2, PWN, Warszawa.

Kuraszkiewicz Władysław (1985), Ruthenica. Studia z historycznej i współczesnej dialektologii wschodniostowiańskiej, PWN, Warszawa.

Moszyński Kazimierz (1921), Uwagi o słowiańskiej terminologii topograficznej i fizjograficznej oparte przeważnie na materiale białorusko-poleskim, Archiwum Nauk Antropologicznych, t. 1, nr 5, Książnica Polska Towarzystwa Nauczycieli Szkół Wyższych, Lwów-Warszawa.

Moszyński Kazimierz (1928), Polesie wschodnie, Wydawnictwo Kasy im. Mianowskiego, Warszawa, s. 1-19.

Nitsch Kazimierz, Stieber Zdzisław (1938), Z pogranicza językowego polsko-białoruskiego, „Sprawozdania Towarzystwa Naukowego we Lwowie” 1938, t. 18, z. 1, s. 34-39.

Nitsch Kazimierz (1954-1958), Wybór pism polonistycznych, t. 1-4, Zakład im. Ossolińskich, Wrocław.

Nitsch Kazimierz (1960), Wybór polskich tekstów gwarowych, wyd. 2, PWN, Warszawa.

Ossowski Leszek (1992), Studia slawistyczne, Zakład Narodowy im. Ossolińskich, Wrocław.

Pietkiewicz Czesław (1928), Polesie Rzeczyckie. Część I: Kultura materialna, PAU, Kraków.

Pietkiewicz Czesław (1938), Kultura duchowa Polesia Rzeczyckiego. Materiały etnograficzne, Drukarnia Techniczna, Warszawa.

Rieger Janusz, Werenicz Wiaczesław (1982), Studia nad polszczyzna kresowa, t. 1, Zakład Narodowy im. Ossolińskich, Wrocław. 
Stochel Włodzimierz (1987), Literackie powiazania polsko-białoruskie w świetle polskich badań naukowych (wczoraj i dziś), w: Studia polono-slavica-orientalia. Acta litteraria, t. 10, Wrocław, s. 289-311.

Tarnacki Józef (1939), Studia porównawcze nad geografia wyrazów (Polesie-Mazowsze), Zakłady Graficzne „Drukarnia Bankowa”, Warszawa.

Tarnacki Józef, red. (1939), Atlas językowy gwar Polesia, Warszawa.

Turska Halina (1995), O powstaniu polskich obszarów językowych na Wileńszczyźnie, wstęp, przypisy Walery Czekmonas, Vilnius „Mintis”.

Баршчэўскі А. i in. (1982), Кафедра беларускай філалогіi на парозе новага 25-годдзя, w: Беларускі каляндар на 1983 год, Выдавецтва ГП БГКТ ў Польшчы, Беласток.

Беларускі каляндар на 1960 год, Выдавецтва ГП БГКТ ў Польшчы, Беласток 1959. Бузук Пётр (1928), Спроба лінчвістычнае геаграфіi Беларусі. Частка I. Фанетыка i марфалогія. Вып. 1. Гаворкі цэнтральнай і ўсходняй Беларусі і суседніх мясцовасцей Украіны і Вялікарасіі ў першай чвэрці XX в., Менск.

Michał Kondratiuk

\section{About cooperation of the team of Byelorussian Philology of the Institute of Slavistic Studies of Polish Academy of Sciences with the Professor Wladyslaw Kuraszkiewicz in the sphere of investigations of dialects}

The article shows the role of Prof. Władysław Kuraszkiewicz in creating and developing Byelorussian investigations in Poland after World War II. In the interwar period he investigated Russian dialects in Podlasie, Polesie and Helm Regions. In 1937 he was the first to collect rich dialectae materials in 70 villages between the Bug and the Narew Rivers, which he published in 1939 The Outline of east-slavonic dialectology with examples of dialectal texts, and edition, Warsaw 1963, made him famous. Prof. Kuraszkiewicz was the reviewer of the first three volumes of the Atlas of East Slavonic Dialects of Bialystok Region (Wrocław 1980-1993).

Before 1985 he initiated the investigations of the Atlas of East Slavonic Dialects of the Bug River Region, carried out by to teams: the Institute of Slavistic Studies in Warsaw and the Institute of Slavistic Studies UMCS in Lublin.

He also contributed to the development of scientific personnel. He promoted and reviewed the doctor's and assistant-professor research. He supported the development of Byelorussian studies and set up "International Association of Byelorussists and Polish Byelorussists Society". 
KEYwords: atlas; Byelorussian; Russian; dialects; investigations; review; research; studies.

prof. zw. dr hab. Michał Kondratiuk - w latach 1960-1992 pracownik naukowy Instytutu Słowianoznawstwa PAN w Warszawie, potem od roku 1992 do 2011 wykładowca Uniwersytetu w Białymstoku; zainteresowania badawcze: gwary wschodniosłowiańskie i polskie oraz onomastyka na pograniczu polsko-białorusko-ukraińskim i słowiańsko-bałtyckim, w północno-wschodniej Polsce i na Białorusi. 
